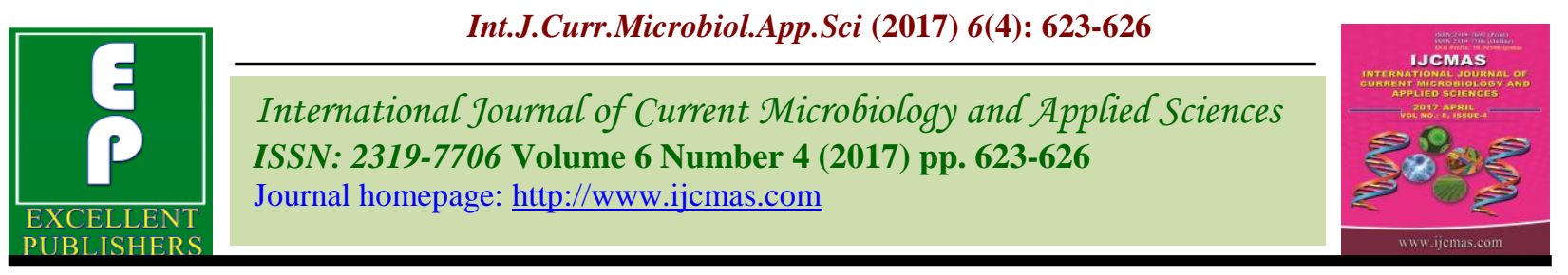

Original Research Article

https://doi.org/10.20546/ijcmas.2017.604.075

\title{
Performance of Different Hybrids and Varieties of Redgram under Central Dry Zone of Karnataka, India
}

\author{
T.N. Dhanalakshmi*, T. Rudramuni and G. Hanumantha Naik \\ AICRP on Castor, ZAHRS, Hiriyur, India \\ *Corresponding author
}

\author{
A B S T R A C T
}

Keywords

Redgram, Hybrid, Central dry zone.

Article Info

Accepted:

06 March 2017

Available Online:

10 April 2017
Pigeonpea (Cajanus cajan L.) is an important multipurpose pulse legume in the tropics and subtropics. The global production of pigeon pea is 4.32 million tonnes from an area of $5.32 \mathrm{~m}$ ha with a productivity of $813.2 \mathrm{~kg} / \mathrm{ha}$. India is the largest producer and consumer of pigeonpea with an area of $3.86 \mathrm{~m}$ ha followed by Myanmar. In spite of huge demand and high price the yield barrier is not broken. To overcome the problem of low productivity hybrid technology or the use of hybrids is preferred; which is one of the components to increase the yield. The present investigation comprised of 22 entries sponsored by IIPR, Kanpur was conducted at the Zonal Agricultural and Horticultural Research Station, Hiriyur, Chitradurga district, Karnataka during 2015-16 kharif season to study their potentiality with respect to yield trait mainly. Analysis of variance showed significant differences for all the characters. This indicates the existence of sufficient variation for effective selection for the characters in the material under study. The genotypeGRG-2013 recorded higher yield of $1806 \mathrm{~kg} / \mathrm{ha}$ followed by CRG-2012-25with a yield of $1720 \mathrm{~kg} / \mathrm{ha}$. It is believed that the hybrid plants are naturally developed at genetic level to produce vigorous plants, in turn greater yields. This is attributed to the interactions among various favorable alleles. The increase in seed yield was due to better synchronization of flowering resulted in increased pod set. The higher yield resulted due to more number of branches, pods per plant as it is one of the important yields attributing character.

\section{Introduction}

Pigeonpea (Cajanus cajan L.) is one of the most important legume crops of India. India contributes to the tune of world's $85 \%$ of the total production. Among pulses, pigeonpea dal is a staple food across the country and plays an important role in National Economic and Nutritional Security.

The annual production of pigeonpea pulse in India is about three million tonnes; but this quantity is insufficient to meet the domestic needs and hence a considerable amount (about 100,000 t) of pigeonpea is imported each year (http//www.ipga).

To breed high yielding cultivars of pigeonpea breeders running out of various methods primarily recommended for self-pollinated crops (Green et al., 1981) and released number of varieties but without any 
significant improvement in its productivity, that remained unchanged over the decades at around $600-800 \mathrm{~kg} / \mathrm{ha}$.

In coming future also, the issue of yield stagnation is likely to be remain more or less same, until a path breaking technology with exceptionally high yield potential is developed. In this regard, the recent success in developing hybrid breeding technology in pigeonpea (Saxena et al., 2013), the first in the world in any grain legume, has generated a lot of positive opinion and energy among pigeonpea breeders to break down the decades-old productivity barrier.

\section{Materials and Methods}

The material for the present study comprised of 22 different entries sponsored by IIPR Kanpur. The seed material was sown in Randomized Complete Block Design with recommended Agronomic and Plant Protection practices were followed during crop growth period to raise a good crop.

The application of recommended dose of fertilizer (25:50:25 NPK kg/ha) applied to the plot. Several yield and yield attributing traits were recorded in pigeonpea.

Each plot consisted 6 rows of $4 \mathrm{~m}$ length with inter and intra row spacing of 90 and $25 \mathrm{~cm}$, respectively. To avoid border effect, one border row was planted at each side of the plot and first and last plant from each row was excluded from the plot yield and yield $\mathrm{kg} / \mathrm{ha}$ was calculated considering net plot area 12.6 $\mathrm{m}^{2}$.

The Agronomic practices included basal application of Recommended Dose of Fertilisers (RDF), two hand weedings and two irrigations were followed.
Data were recorded on days $50 \%$ flowering, Plant height $(\mathrm{cm})$, plant stand at the time of harvesting, Number of primary branches/plant, Number of secondary branches/plant, Number of pods/plant, 100 seed weight (g) and yield (kg/ha). The statistical analysis was performed using AGROBASE GEN-II software.

\section{Results and Discussion}

It is believed that the hybrid plants are naturally planned at genetic level to produce vigorous plants, greater yields and maintaining their stability. This is attributed to the interactions among various favourable alleles.

It was noted that pigeonpea hybrid plants start showing hybrid vigour right from the early seedling stage. In comparison to pure lines, the hybrids have higher yield potential (Bharathi and Saxena, 2012; Thakre et al., 2013).

Analysis of variance showed significant differences for all the characters. This indicated the existence of sufficient variation for effective selection for these characters in the material under study (Table 1).

The genotype GRG-2013 recorded higher yield (1806 kg/ha) followed by CRG-2012-25 with a yield $(1720 \mathrm{~kg} / \mathrm{ha})$. Hybrids have more potential and believed that they are naturally programmed at genetic level to produce vigorous plants, greater yields and stability.

The increase in seed yield was due to better synchronization of flowering resulted in increased pod set. The higher yield resulted due to more number of pods per plant as it is one of the important yields attributing character. 
Table.1 Analysis of variance for yield and yield attributing characters in different pigeon pea hybrids and varieties

\begin{tabular}{|l|c|c|c|c|c|c|c|}
\hline \multicolumn{1}{|c|}{ Entries } & $\begin{array}{c}\text { Yield } \\
\text { (kg/ha) }\end{array}$ & $\begin{array}{c}\text { Days } \\
\text { to 50\% } \\
\text { flowering }\end{array}$ & $\begin{array}{c}\text { Plant } \\
\text { height } \\
\text { (cm) }\end{array}$ & $\begin{array}{c}\text { Number of } \\
\text { primary } \\
\text { branches } \\
\text { /plant }\end{array}$ & $\begin{array}{c}\text { Number of } \\
\text { secondary } \\
\text { branches } \\
\text { /plant }\end{array}$ & $\begin{array}{c}\text { Number } \\
\text { of pods } \\
\text { /plant }\end{array}$ & $\begin{array}{c}\text { 100 seed } \\
\text { weight } \\
\text { (g) }\end{array}$ \\
\hline RVSA 7-15 & 1380.0 & 73.0 & 191.7 & 11.3 & 5.0 & 173.0 & 12.1 \\
\hline GJP 1406 & 1470.0 & 82.0 & 214.0 & 10.7 & 6.7 & 158.0 & 12.2 \\
\hline LRG 117 & 1174.0 & 81.3 & 172.0 & 12.3 & 4.0 & 167.0 & 13.0 \\
\hline TRG 59 & 1479.0 & 83.0 & 169.0 & 11.3 & 5.7 & 100.3 & 12.0 \\
\hline LRG 170 & 1273.0 & 82.3 & 200.3 & 13.0 & 4.7 & 242.3 & 11.0 \\
\hline GRG 2013 & 1806.0 & 81.7 & 176.0 & 11.3 & 3.3 & 255.3 & 11.2 \\
\hline BRG 15-1 & 1199.0 & 87.3 & 213.0 & 8.7 & 5.0 & 93.3 & 13.7 \\
\hline CRG 2012-30 & 1498.0 & 70.7 & 206.7 & 12.0 & 3.3 & 217.0 & 10.1 \\
\hline BRG15-2 & 1220.0 & 84.0 & 218.7 & 12.7 & 4.3 & 225.7 & 15.1 \\
\hline RVSA 7-17 & 1282.0 & 81.0 & 200.0 & 12.3 & 5.7 & 112.3 & 9.9 \\
\hline GJP 1401 & 1535.0 & 81.3 & 233.3 & 12.0 & 4.3 & 167.7 & 12.1 \\
\hline BDN 2008-7 & 1609.0 & 71.0 & 203.7 & 10.0 & 5.3 & 133.3 & 11.8 \\
\hline WRG 242 & 1030.0 & 81.0 & 202.0 & 12.0 & 3.3 & 192.7 & 11.5 \\
\hline RPS 2007-10 & 1678.0 & 71.0 & 217.3 & 12.3 & 4.0 & 156.7 & 12.3 \\
\hline CRG 2012-25 & 1720.0 & 80.3 & 212.7 & 12.3 & 6.7 & 235.0 & 9.4 \\
\hline AKTE 12-02 & 1512.0 & 77.3 & 214.0 & 11.3 & 3.7 & 155.0 & 11.4 \\
\hline BSMR 243 & 1678.0 & 72.3 & 217.0 & 12.7 & 5.0 & 171.3 & 11.5 \\
\hline RKPV 4121-02 & 1053.0 & 73.0 & 126.7 & 10.7 & 3.7 & 102.7 & 10.4 \\
\hline WRG 252 & 1477.0 & 74.0 & 222.7 & 13.7 & 3.3 & 197.3 & 10.4 \\
\hline ICP 8863 (C) & 1444.0 & 74.7 & 180.0 & 10.0 & 6.0 & 122.7 & 9.2 \\
\hline WRP-1 (C) & 1400.0 & 73.7 & 193.7 & 12.7 & 5.0 & 198.3 & 10.2 \\
\hline CO 6 (C) & 1576.0 & 76.3 & 229.7 & 10.0 & 6.7 & 180.3 & 8.6 \\
\hline SEm \pm & 75.02 & 0.7 & 5.52 & 0.72 & 0.44 & 9.78 & 0.31 \\
\hline CD (0.05P) & 232 & 2 & 15.77 & 2.06 & 1.27 & 27.91 & 0.88 \\
\hline CV(\%) & 10 & 1.56 & 4.77 & 10.77 & 16.18 & 9.92 & 4.74 \\
\hline
\end{tabular}

\section{Acknowledgement}

The experiment was supported by Indian Institute of Pulses Research (IIPR), Kalyanpur, Kanpur, Uttar Pradesh and Zonal Agricultural and Horticultural Research station, Hiriyur, Karnataka.

\section{References}

Bharathi, M. and Saxena, K.B. 2012. A comparative study of hybrid and inbred cultivars for germination and other related traits of pigeonpea. J. Food Legumes, 25: 351-354.

Green, J.M., Sharma, D., Reddy, L.J. Saxena, K.B., Gupta, S.C., Jain, K.C., Reddy, B.V.S., and Rao, M.R. 1981. Pages 437449. In: Int. J. Scientific and Res. Publications, Volume 5, Issue 6, ISSN 2250-3153.

http//www.IPGA. 2012. Pulse Export and Import Trade. India Pulse and Grain Association.

IIPR. 2013. All India Coordinated Research Project on Pigeonpea. Project Coordinator's Report. Indian Institute of Pulses Research, Kanpur, 13-14 May, 2013. Pp 49. 
Saxena, K.B., Kumar, R.V., Tikle. A.N., Saxena, M.K., Gautam, V.S., Rao, S.K, Khare, D., Chauhan, Y.S., Saxena, R.K., Varshney, R.K., Reddy, B.V.S., Sharma, D., Reddy, L.J., Green, J.M., Faris, D.G., Mula, M., Sultana, R., Srivastava, R.K., Gowda, C.L.L. and Sawargaonkar, S.L. 2013. ICPH 2671 - The world's first commercial food legume hybrid. Plant Breeding, 132: 479485.

Thakare, D.P., Mula, M.G., Mehtre, S.P., Saxena, K.B., and Rathore, A. 2013. Seedling vigour study in pigeonpea (Cajanus cajan (L.) Mill sp.) hybrids and varieties. J. Food Legumes, 26: 100-102.

\section{How to cite this article:}

Dhanalakshmi, T.N., T. Rudramuni and Hanumantha Naik, G. 2017. Performance of Different Hybrids and Varieties of Redgram under Central Dry Zone of Karnataka. Int.J.Curr.Microbiol.App.Sci. 6(4): 623-626. doi: https://doi.org/10.20546/ijcmas.2017.604.075 